\title{
State Intervention and Privatization of Family Life
}

\author{
RIITTA JALLINOJA \\ Assistant \\ ELINA HAAVIO-MANNILA \\ Associate Professor \\ Department of Sociology \\ University of Helsinki
}

\section{Features of societal development in Finland}

Finland remained an agricultural country longer than most of the other western countries which are now at about the same economic level. Until the Second World War people living by agriculture formed the majority of the whole population: in 1900 the proportion was $68 \%$, and in 1930 still $60 \%$. The decisive change in the structure of industry, however, took place after the War. The number of people working in agriculture decreased especially in the sixties (Table 1). This change was more rapid than ever before or after during an equivalent period of time.

$\mathrm{T} \mathrm{a} \mathrm{b} \mathrm{l} \mathrm{e} \mathrm{1.} \mathrm{Quantitative} \mathrm{changes} \mathrm{in} \mathrm{the} \mathrm{numbers} \mathrm{of} \mathrm{economically} \mathrm{active} \mathrm{people,}$ by industry, $1950-1975$.

$\begin{array}{ccccc}\text { Period } & \text { Agriculture } & \text { Manufacturing } & \text { Service } & \begin{array}{c}\text { Total number of } \\ \text { economically active } \\ \text { people in the } \\ \text { beginning of } \\ \text { the period }\end{array} \\ 1950-60 & -191,172 & +89,685 & +150,473 & 1,984,282 \\ 1960-70 & -291,807 & +86,758 & +290,038 & 2,033,268 \\ 1970-75 & -110,922 & +29,080 & +84,759 & 2,118,257\end{array}$

Most of the people who left agriculture moved straight to the service sector, for the number of people working in manufacturing increased by only a third of the number who left agriculture at the same time. The need for labor outside agriculture was so great in the sixties that the people who left agriculture could not satisfy that need. One important source of labor could have been the children of the late forties' baby boom. They reached working age in the late sixties, but many of them postpon- 
ed entering the labor market because they were continuing their education. It was necessary to resort more and more to the labor of married women. The number of economically active women in urban municipalities increased by 140,000 in 1960-70.

Besides the fact that Finland was for so long dominated by agriculture, manufacturing was also in close contact with rural culture. Until the Second World War more than half (52-53 \%) of the people working in manufacturing lived in rural municipalities. By 1950 the proportion of rural manufacturing had declined to $39 \%$, from which it further decreased to $31 \%$ in 1975 . This situation was caused mainly by the fact that the most important branch in manufacturing was wood and paper manufacturing. Its natural place is in the neighbourhood of forests and rivers. Thus, rural culture was part of Finnish manufacturing and the urban working class culture that developed was not as powerful as that of many countries in Central Europe. In spite of this, socialist doctrines reached the workers and also the landless population in rural areas. In the first parliamentary elections in 1907, the Social Democrats gained $40 \%$ of the seats in Parliament (Soikkanen 1961).

If Finnish manufacturing was characterized by rural culture before the Second World War, agriculture itself had its special features, too, which have had an impact on family life patterns, especially concerning women. Finnish agriculture has been dominated by small farms. This was caused both by the dissolution of the crofter institution during the first half of this century and by the settlement of Karelian evacuees after the Second World War.

New farms were established mainly in the twenties, when the so-called crofter law came into force, and even more in the forties, when there was a vast number of new settlements. The great majority of the new farms were under 10 hectares in size. There were still new farms being established in the fifties, though the population in rural municipalities had begun to decrease. In Finland, the fifties were in a way, a time of peasantry. In this respect the 1960's brought a real change: the number of farms decreased by nearly 100,000 or by a quarter. Most of the farms which closed down were under five hectares.

In the 1960's other kinds of changes also occurred in agriculture. The agricultural population began more and more to resort to wage work outside the farm. In 1950 $9 \%$ of all the working hours of farmers and their family members were spent in wage work outside the farm. By 1962 the proportion of wage work had increased to $20 \%$. During the sixties the proportion remained on the same level $(22-23 \%)$, but it declined in the seventies to $15-17 \%$. At the same time, as wage work increased among farmers in the sixties, the use of hired labor on farms decreased. This meant that landless people had to move to other industries. The importance of agriculture diminished in this way, too. In 1950,14 \% of all working hours spent on farms were those of farm workers; at the beginning of the sixties the proportion has declined to $7 \%$. It decreased later in the sixties to $4-5 \%$, in the seventies to $2-3 \%$.

Living conditions became more difficult in the countryside also for the reason that the need for workers in forestry diminished because of the mechanization of 
timber felling in the sixties. In 1960 the number of workers in forestry was 112,000 (in 1950 it was about the same: 117,000 ), but in 1970 the number was 62,000 . It diminished further during the next five years (to 38,000 ). In this way, the importance of forestry as a typical secondary occupation in agriculture has drastically decreased. But because wage work became more frequent among farmers in the sixties, it meant that farmers and their family members began to work more and more in the manufacturing and service sectors. Thus farmers, too, began little by little to adopt urban life patterns.

Because the proportion of small farms was still slightly over $50 \%$ in the $50 \mathrm{~s}$, the life pattern formed on small farms also influenced family life. One can assume that on modest farms it is impossible to develop a bourgeois life pattern, which generally includes only a slight share of female (wife's) work. According to Saurio $(1947,53)$, the wives of small farmers took more often part in agricultural work than the wives of big farmers. On farms of under 25 hectares over $90 \%$ of housewives took part in agricultural work, compared with $76 \%$ on farms of $25-50$ hectares. On farms of over 50 hectares the proportion was only $37 \%$. It seems probable that the dominance of small farms in Finnish agriculture has been one factor which has helped Finnish women to participate also in wage work. Without their hard work on small farms the proportion of females among the economically active population would perhaps have been smaller.

If we examine the factors influencing family life patterns in Finland, we must refer to the above features. But in addition, we must pay attention to the speed of the changes in the industrial structure in the sixties. One long period reached its end at the beginning of the 60 's and another period began. The interesting feature in this process is that it was preceded by the decade when agriculture actually experienced a relatively strong revival through new settlements. It is perhaps for this reason that the changes in the 60 's were so drastic.

\section{The increase in the number of gainfully employed married women}

The rapid change in the industrial structure in the 60 's furthered the increase in the number of gainfully employed women, because agriculture could not provide enough workers to satisfy the needs of the expanding manufacturing and service sectors. Prolonged education kept the baby boom generation outside the labor market. The proportion of economically active in the age group 15-19 dropped among women from $53 \%(1950)$ to $23 \%$ (1975) and among men from $74 \%$ (1950) to $31 \%$ (1975).

In Finland there has been practically no immigrant labor. Apart from the people who have left agriculture, the only important source of labor has thus been women. In the sixties the proportion of women in the increase of the labor force began to be greater than that of men. The same tendency continued in the 70's. Because of 
this process, the proportion of women in the whole labor force outside agriculture increased from $41 \%$ in 1950 to $46 \%$ in 1975 .

The great majority of the increased female labor force were married women. Already from the beginning of this century unmarried women had generally been gainfully employed; thus their significance as a source of labor has been slight. Married women, however, had seldom been gainfully employed outside agriculture. In 1920 only $10 \%$ of all married women in towns were gainfully employed. By 1950 the proportion had increased to $34 \%$, in 1960 it was $45 \%$, in 1970 already $57 \%$ and in 1975 as high as $65 \%$. It is remarkable to note that married women began to move into the labor market already in the 50's, although the proportion of women among the whole labor force had not yet increased. Thus internal changes have occurred in the labor market: when the marriage rate increased, married women replaced unmarried women in the work force. It was not until the 60 's that the number of married women entering the labor market became so great that they could increase the proportion of women among the whole labor force.

The numbers of gainfully employed married women increased at an unprecendented rate in the 60 's and in the 70's. Married women have thus formed a remarkable source of labor, especially during these decades. One can assume that this process has had a great impact on family life, which thus probably formed a basis for change in the 60 's.

Marriage scarcely ever prevents Finnish women from working outside the home any more. Nowadays not even children prevent the mother from being gainfully employed. Figure 1 shows that in 1950 the increase in the number of children in the

F i g u r e 1. The proportion of gainfully employed married mothers of all married mothers by the number of children in urban municipalities, 1950-75.

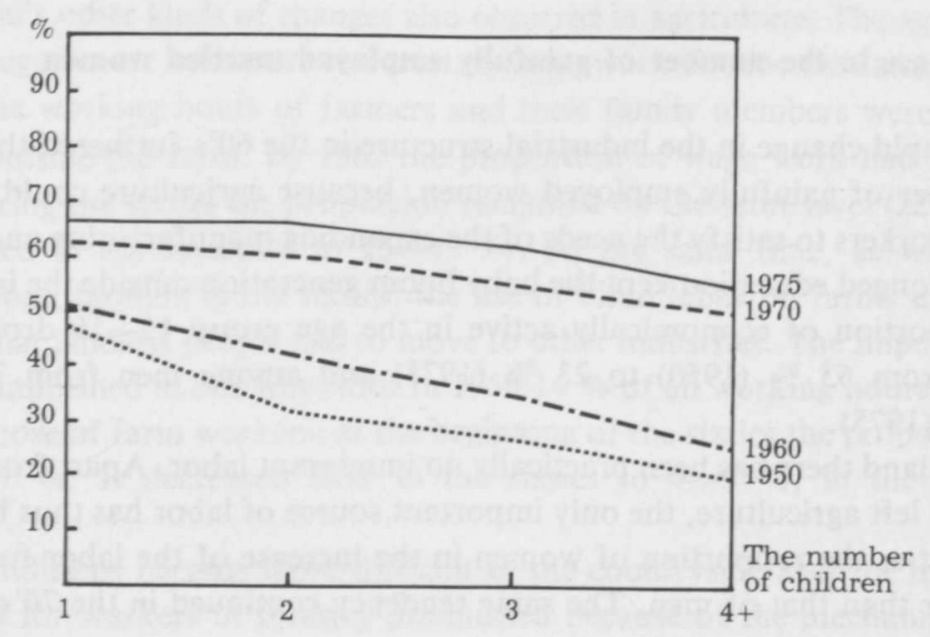


family still clearly decreased the mother's work outside the home. In 1960 the situation was basically the same as in 1950 , with the difference, however, that the proportion of gainfully employed mothers increased in families of every size. By 1970 the situation had changed decisively and still more so by 1975; the increase in the number of children in the family caused practically no decrease in the proportion of gainfully employed mothers. Instead, the age of the youngest child still influences the willingness of mothers to work. In $1975,61 \%$ of mothers with children under school age ( $0-6$ years) were gainfully employed; the proportion of gainfully employed mothers with the youngest child $7-15$ years old was $75 \%$, and with the youngest child over 15 years old, $55 \%$. In 1979, already $74 \%$ of the mothers of children under school age worked for pay, according to the results of the timebudget study made by the Central Statistical Office.

In 1920 the frequency of the employment of married women hardly varied at all in different social classes, when class position is defined by the husband's occupation. The percentages were close to the average of all married women, i.e. $10 \%$. There were practically no differences in 1950, either. Among the wives of employers $37 \%$ were gainfully employed, the proportion among the wives of administrative and clerical employees was $36 \%$ and among the wives of workers, $38 \%$. In 1960 the proportions of gainfully employed wives in towns were as follows: among the wives of upper administrative and clerical employees $41 \%$, among the wives of lower administrative and clerical employees $47 \%$, among the wives of workers $46 \%$, and among the wives of managers $34 \%$. Only the last-mentioned small group formed an exception: the wives of managers were less often gainfully employed than all married women on the average. Thus the bourgeois family life pattern is more typical among families with high salaries and high social status. This kind of life pattern is not the rule, however. In this group, also, the employment of wives has become more common, though more slowly than in other groups. We have no good statistics for the year 1970, but according to some studies the employment of wives has increased in all social classes, although most among the wives of middle-salaried husbands (Uusitalo 1975, 123). A small wealthy part of the population practices to some extent even today the traditional sexual division of labor, according to which the woman's place is in the home.

The employment of married women is strongly related to the times. It has become more common in every social group and its prevalence has been rather even. The process was, however, most rapid in the 60's and 70's, when the need for labor was also greatest. It was rather easy to draw married women into the labor market, because already at the beginning of this century the employment of women was almost as common as it was just after the last war. This was because of the low marriage rate at the beginning of the 20th century. In 1910, $39 \%$ of all the gainfully employed outside agriculture were women. In 1920 the proportion of women was $41 \%$, and it stayed on this level until 1960 (Jallinoja 1976, 37). A gainfully employed woman, though she was most often unmarried, became a familiar and thus gradually accepted phenomenon. Although the employment of married women was not fully accepted among the population in the 50 's, the employment of married 
women became more and more common. Attitudes changed very clearly in the late sixties, when we had a very lively debate in Finland about equality between the sexes. One of the particular demands concerning this equality was the right of married women to work outside the home. Women themselves were especially active in advocating this right.

Although the employment of women was already rather common at the beginning of this century, it was still more firmly connected to the family than was the case with men. This is understandable, because the family had for a long time formed the most important life area for women. In agriculture women have been called "family workers». This concept is characteristic: the woman was also seen as an employed person connected to the family, and not as an independent employer (selfemployed worker) as her husband was seen. At the same time she was considered her husband's helper. This long tradition became a model for a great deal of wage work.

We meet the same kind of situation among servants as we found in agriculture. In the latter half of the last century half of the gainfully employed women in towns were servants (Jallinoja 1976, 39). Servants worked in families and thus the family formed the work community for these women. In handicraft families the wife very often worked as an assistant to her husband, becoming so familiar with the job that she could inherit the right to the job after her husband's death. She did not, however, have the right to an independent trade during her husband's lifetime (Kalenteri . . 1894, 21 and 105). In restaurants and cafés and also in trade, women were often in the position of a servant; they often lived with their employer's family, forming with this family a rather firm work community. Even in some state occupations female workers had to spend part of their work time as servants (Koti ja yhteiskunta 1890). Besides these family-related occupations, women had paid work at home, too. So-called home manufacturing was still relatively common at the beginning of this century (Voionmaa 1905, 27). In this way women's work, although it has been paid, has also been characterized by a connection to either the woman's own or some other family. The family has in one way or another formed the woman's working community.

Part-time work must also be seen as a symptom of the close connection for women between work and the family. It allows women responsibility for housework more surely than does full-time work. In $197525 \%$ of female part-time workers had chosen part-time work because they could thus better combine paid work and housework (Central Statistical Office 1976, 18). Part-time work, however, is less common in Finland than in most other capitalist countries. In $197912 \%$ of all gainfully employed women were working part-time. The corresponding proportion among men was $1 \%$. Finnish women are thus, first, very commonly gainfully employed, with this applying also to married women, and secondly they mostly work full-time. They do not have great possibilities for combining child care and work, because most women are wage workers outside the home. The change which occurred in the 60 's and 70's concerned, above all, women with families. Their life 
pattern is now dominated by full-time salaried work. The time spent in the family is now limited for women also to evenings, week-ends and holidays.

\section{Marriage and the family}

The debate about equality which arose in the late sixties meant that more attention was paid to marriage. As a result of this debate in 1970, the Government appointed a committee to prepare a proposal for a new marriage law. The committee finished its work in 1972. The attitudes of the committee were presented in the report and one can find that these were very close to the ideas presented by Association 9, which was the leading organization in the sex role debate. The tendency towards liberalization expressed itself in the demands for facilitating the divorce process. The claim was based on the view that the emotional function has become more important in modern marriage (Avioliittolakikomitea 1972, 48). In addition the committee was faithful to other attitudes of the sixties: it pointed out the role of the state as guarantor of successful marriages. The report of the committee thus contained the two elements which dominated the ideological debate in the 60's; on one hand, individual freedom of choice was emphasized, but on the other hand state intervention was demanded.

A new marriage law has not yet come into being. In spite of this, Finnish marriages have changed. In the following pages we examine some of the changes which we consider to have had an impact on Finnish family life.

Because marriage is still the most important foundation for the family, we first examine changes in marriage rates during this century. Figure 2 shows that the proportion of ever-married in the age group 35-39 years has varied relatively strongly. The marriage rate was very low during the first three decades. This was especially true in towns and for women. But men, too, remained rather commonly single. In 1920 , when the marriage rate was at its lowest, the proportion of ever-married among women in towns was only $57 \%$ and among men $65 \%$. This evidence leads us to suppose that some factors had really made it more difficult to set up a family at the beginning of this century. The situation may have been caused by a societal change which weakened the economic preconditions for setting up a family. This tendency was also strengthened by the relatively common employment of young women. The Finnish family experienced in that way a rather peculiar revolution at the beginning of this century; in towns, especially, a good part of the population was deprived of the possibility of setting up a family.

The marriage rate became higher after the Second World War. The same kind of tendency was seen in all Nordic countries, but in Finland the change was most marked, because marriage rates before the War were on such a low level. It is probable that the change in marriage rates was connected with economic growth and the increase of mobility. In any case, the result was that most people could set up a family. 
F i g u r e 2. The proportion of ever married in the age group 35-39 in towns, $1900-1975$.

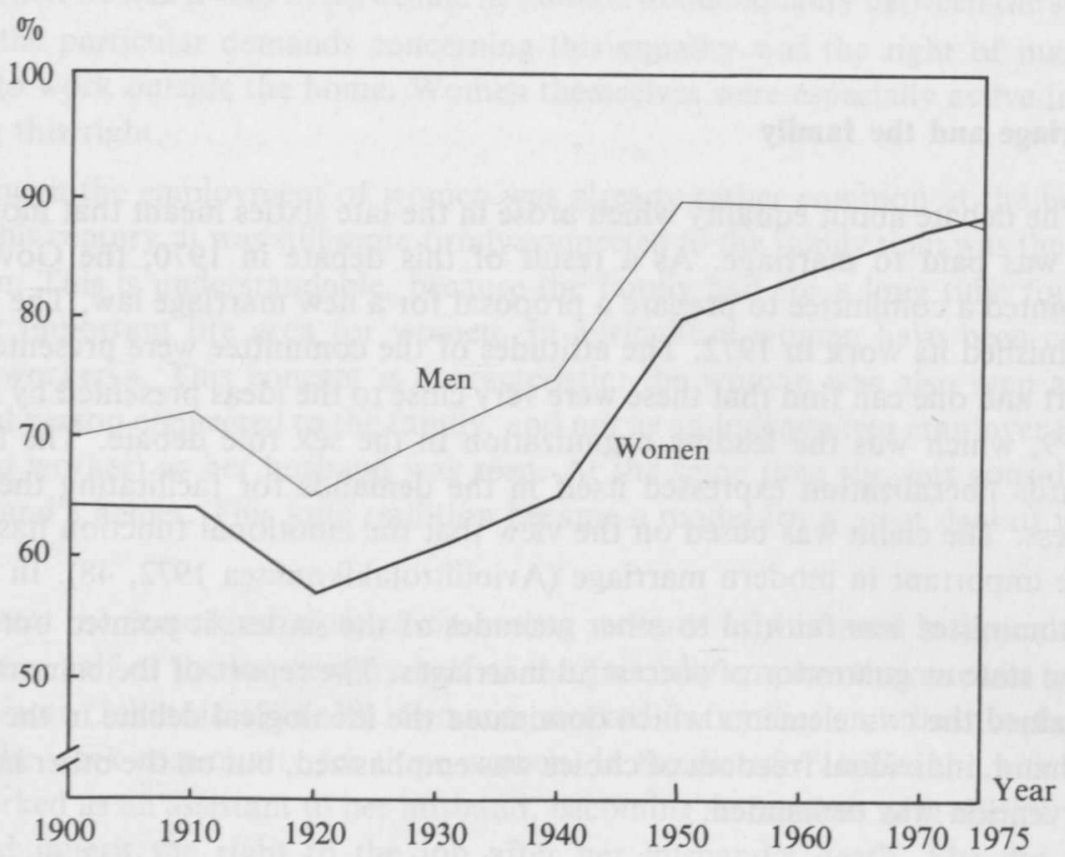

The prevalence of marriage meant that a large proportion of gainfully employed women were married. It was, perhaps, impossible to give up the use of female labor, so that when the number of unmarried women declined, it was necessary to turn to married women on the labor market. We must thus consider that the frequency of the unmarried state at the beginning of this century, and especially the strong prevalence of marriage after the War are essential historical features in Finland which brought about the relatively early employment of married women.

Divorce began to increase at about the same time that marriage began to become more frequent. It is probable that these phenomena were connected with the same process. The first culmination was reached just after the World War, when many war-time marriages were dissolved. After that, the number of divorces declined. This new level lasted until the end of the 60 's. In this respect we can regard this period as quite stable. A change occurred at the turn of the seventies, when the number of divorces began to increase. This tendency continued during the 70's. For the family, this period can be considered unstable. The dissolution of marriages occurred at about the same time as societal change was very strong. Economic growth did not at this time guarantee the maintenance of the family; it guaranteed high marriage rates, but not the maintenance of the marriages. The idea of easing the divorce process, presented in the report of the marriage law committee, was thus based on the real situation, i.e. on the actual prevalence of divorce. 
Though divorce became more frequent, the number of one-parent families did not increase. In many cases divorced people entered a new marriage. Men have entered a new marriage slightly more often than women have. That is why women have remained more often alone or with children than men have. In 1975, in the age group 20-49 years, there were 42,300 lone widowed or divorced men and fathers with children. The respective number of women was much higher, 133,800. The numbers show that the dissolution of marriage, now mostly through divorce among people under 50 years of age, means living alone or in single-parenthood more often for women than for men.

Although marriage is still the most common foundation for the formation of the family, cohabiting has become more frequent. In 1978, according to a survey, $5 \%$ of all people over 15 years of age live with their partners without formal marriage. $13 \%$ of the same population has at some time in their lives had experience of this kind of cohabiting (Aromaa et al. 1979, 47). Cohabiting is more common among young people and these alliances generally last a rather short time. It is common that they end with the formalization of the partnership, i.e. with marriage. According to another study, cohabiting became very common among young people in the 70's. In Tampere (a city with 150,000 inhabitants), $58 \%$ of all couples who announced their banns in 1975 had the same address, which has to be interpreted as cohabiting (Sihvo 1976, 55). Cohabiting does not seem to differ from family life based on formal marriage; the life patterns are very similar. Instead, it can be assumed to reflect the abandonment of control formalities prevailing in society and in that way also the privatization of marriage.

\section{The structure of the family}

The changes occurring in the rates of marriage and divorce have influenced the structure of households. Besides these factors, the difference in the average life span of men and of women has an effect on the extent of living alone among old people. Because the mean life expectancy of men in 1975 was much lower (68 years) than that of women ( 77 years), there are much more widows than widowers in the population.

Table 2 shows the proportion of households of various types in the whole country.

The most common type of household has been a family with parents and children. The proportion of these families has declined, however. This has not been caused by the decline of marriage rates, but by the strong increase in the number of men and women living alone.

Not all couples consist only of the nuclear family. Some households also include one or more relatives. Extended families were earlier rather common in areas of primitive agriculture. This was also the case in Finland, where extended families were more common in the eastern parts of the country. There, slash-and-burn re- 
mained an important method of cultivation later than in western parts of Finland (Voionmaa 1969, 430). In addition, extended families were met with more often in tar-burning areas (Ylikangas 1976, 270). The proportion of households 200 years ago with two or more families could reach in some municipalities as high a percentage as $40 \%$ of all households (Jallinoja 1976, Appendix 17).

$\mathrm{T} \mathrm{a} \mathrm{b} \mathrm{l} \mathrm{e} \mathrm{2.} \mathrm{The} \mathrm{proportion} \mathrm{of} \mathrm{households} \mathrm{of} \mathrm{various} \mathrm{types,} \mathrm{1950-1975.}$

$\begin{array}{lcccr} & 1950 & 1960 & 1970 & 1975 \\ \text { Type of household } & \% & \% & \% & \% \\ \text { Couple without children } & 15,5 & 15.8 & 17.4 & 17.9 \\ \text { Couple and children } & 52.2 & 51.4 & 48.2 & 45.3 \\ \text { Mother and children } & 12.1 & 9.8 & 8.8 & 8.6 \\ \text { Woman living alone } & 12.6 & 14.7 & 16.7 & 18.4 \\ \text { Father and children } & 2.0 & 1.5 & 1.3 & 1.4 \\ \text { Man living alone } & 5.6 & 6.8 & 7.5 & 8.5 \\ \text { All households } & 100.0 & 100.0 & 100.0 & 100.0\end{array}$

$\mathrm{T}$ a b l e 3. The proportion of extended families (families with relatives) of all families, 1970 and 1975.

$\begin{array}{lcccc} & \begin{array}{c}1970 \\ \text { urban } \\ \%\end{array} & \begin{array}{c}\text { rural } \\ \%\end{array} & \begin{array}{c}1975 \\ \text { urban } \\ \%\end{array} & \begin{array}{c}\text { rural } \\ \%\end{array} \\ \text { Province of Uusimaa } & 7.9 & 10.8 & 4.5 & 8.0 \\ \text { Province of Turku and Pori } & 6.5 & 14.8 & 4.7 & 9.0 \\ \text { Province of Häme } & 7.0 & 14.5 & 4.9 & 9.5 \\ \text { Province of Kymi } & 12.9 & 20.9 & 5.9 & 16.9 \\ \text { Province of Mikkeli } & 17.2 & 22.3 & 5.6 & 17.1 \\ \text { Province of Pohjois-Karjala } & 9.7 & 18.0 & 7.6 & 13.9 \\ \text { Province of Kuopio } & 11.3 & 22.7 & 7.7 & 17.0 \\ \text { Province of Keski-Suomi } & 8.8 & 17.3 & 5.8 & 13.2 \\ \text { Province of Vaasa } & 7.8 & 17.2 & 6.1 & 12.9 \\ \text { Province of Oulu } & 15.0 & 18.4 & 6.5 & 13.9 \\ \text { Province of Lappi } & 8.4 & 16.5 & 6.9 & 12.4 \\ \text { The whole country } & 9.9 & 16.6^{1} & 5.3 & 12.2^{1}\end{array}$

Including servants living in the employer's household. Their number is small, however.

The most common extended family type in the 70 's consisted of the nuclear family and one relative. In $1975,80 \%$ of all extended families were of this type. The remainder mostly had two families in the same household. In both years the proportion of extended families was greater in the countryside than in towns. 
The proportion of extended families has very much decreased. The change is remarkable when we remember that here we are examining a period of only five years. Extended families have become more rare in eastern Finland, too, but still the phenomenon has remained more common there than in western Finland. Extended families have remained more persistently in former burnt-clearing areas, even at a time when the production methods no longer necessarily favor extended families with a large labor pool.

The nuclear family has become more common also in the sense that households now more often have no 'outsiders'. The lodger system was quite common among workers at the turn of the century. For instance, in Helsinki, in a working class part of town, $45 \%$ of working class families had let a part of a room to a lodger in 1900. Most of the lodgers lived in the same room as the host family. The situation was considered normal, because most of the workers had moved from the countryside, where servants and their employer families had in many cases lived together (Waris 1973, 175-176). Servants were another group of outsiders in the family. Earlier it was normal that the servant lived in the employer's household. In 1950, about 60 $\%$ (i.e. 23,275 ) of all servants still lived in the employer's household. The proportion declined very much in the 60 's; by 1970, servants living with the employer's household had declined to $22 \%$ (i.e. 6,595). By 1975 their proportion had further declined, to $10 \%$ (i.e. 1,820). The result of all these tendencies has been that the family consists more and more often solely of a nuclear family.

\section{Children}

The care of children is often mentioned as the first function of the family. Societal development has also affected this function, though perhaps not to such an extent as could be assumed on the basis of the rapid change during the last fifteen years. The number of children in the family declined, not in the 50's, but in the 60 's and 70 's.

$\mathrm{T}$ a b l e 4. The average number of children under 18 years in all families with children in 1950-75.

$\begin{array}{ccc}\text { Urban } & \begin{array}{c}\text { Rural } \\ \text { municipalities }\end{array} \\ 1950 & 1.90 & 2.41 \\ 1960 & 1.95 & 2.49 \\ 1970 & 1.83 & 2.17 \\ 1975 & 1.69 & 1.93\end{array}$

The factor which made the number of children in the family still remain so high in 1960 was the baby boom of the late 40's. The average number of children in the 
family began to decline in the 60 's. The tendency has been the same in both towns and rural areas. The differences between urban and rural municipalities have become smaller, although they still exist.

The changes in fertility rates (Figure 3) are important for the analysis of Finnish society. The most crucial fact there is the baby boom in the late 40's. This created so-called »large age classes». It is essential to notice that this phenomenon was characteristic mainly of the rural municipalities. These age classes in the countryside were the source of the great migration in the 60 's. When young people moved to towns, there were fewer and fewer families in the countryside to give birth to children, and that is why the decrease in the fertility rate in rural areas was so drastic compared to urban areas. At the end of the 60 's the fertility rate was on so low a level that the net reproduction rate remained under one. This means that the newborn girls cannot in turn replace their mothers as reproducers of new life. This period, which has lasted right up to the present, can be considered crucial in the history of Finnish family life.

The great majority of children are born into a family with two parents. Three periods can be found in the rates of births outside marriage. The first consists of the years 1945-51, when the proportion of these births among all live births was rather high. This can be interpreted by the War having created uncertain cir-

F i g u r e 3. Net reproduction rates in urban and rural municipalities, 19451977.

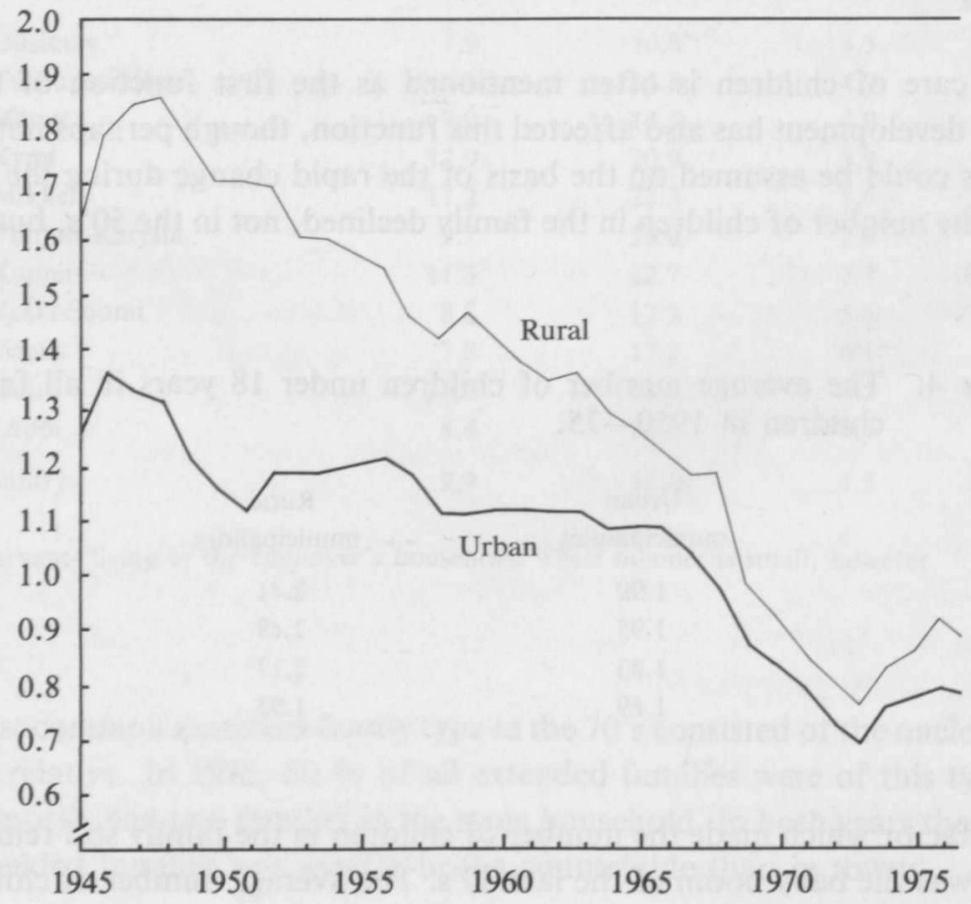


cumstances. In the 50's and the greatest part of the 60 's births outside of wedlock were rather rare. This period can be considered stable. A new increase occurred in the 70's. A great part of the explanation of this phenomenon is the frequency of cohabiting. This means that children born out of wedlock as a matter of fact live in families with two parents. Births outside marriage are not now a symptom of instability or somehow bad circumstances, but a symptom of the privatization of marriage and other human contacts.

Though most children are born into families and most children also live in families, some children are obliged to live under institutional care. The number of children living in different kinds of institutions has always been small, however. In $1960,0.6 \%$ of children under 15 years were in institutional care. In 1976 the proportion was about $0.5 \%$.

The tendency has been that fewer and fewer children are separated from their parents. Another important fact is that about half the children who cannot live with their parents have been placed in other families. This has been the situation after the Second World War. Before the War the proportion of children living in foster care was much higher. That must be interpreted by the fact that families are no longer so eager to take charge of children not their own. This may be one side of the phenomenon that the nuclear family has become the center of family ideology; there is no room for outsiders in the family. This is the case in spite of the improvement in living conditions, which, however, have improved the possibilities of families to take care of their own children.

The above material proves that children are an essential part of the family and that the majority of children live in their own families. The only thing which has changed is the average number of children in the family. This is not an unimportant factor, but its consequences to the family life pattern cannot be described by statistics. There is still one thing which is supposed to have changed during recent decades, and that is the daily care of children. The basis for this supposition is the increasing employment of mothers.

The most essential feature of the sexual division of labor has been the fact that women have mainly been responsible for the care of small children. The most natural care given has been a child's own mother, because the mother has breast-fed the child. This has not, however, meant that the mother has always been the only one who has taken care of her children. A division of labor has also appeared in this respect. According to archive material, people who took care of small children in Finnish rural areas at the end of the last century, were, besides the mother, the grandmother, sister or sometimes brother of the child and a young nurse. The division of labor was thus arranged inside the family, and its function was to release the mother for agricultural work, which was heavier than child care. If the child needed breast-feeding, the mother could do this in between working.

Although the child's own mother was not the only one taking care of the child, she had major responsibility for providing care. When wage labor became more common, it was men who were first employed. Mothers stayed at home. This was the new form of the sexual division of labor and it continued until the 50's. In connec- 
tion with this sexual division of labor, we will first have a look at the frequency with which mothers have taken care of their children themselves. The changes in this respect can be seen in Table 5 .

Mothers have taken full-time care of their own children ( $=$ not been employed) very commonly in the 50's and quite frequently also in the 60 's. In the 50's the main reason for this situation was that the proportion of mothers living by agriculture was so high. In such a case, it is rather easy for a mother to take care of her children throughout the day. Though the information in the Table 5 is not comparable to the other years, it is interesting, however, to see that the proportion of housewives became rather high in 1960 . This was because the decrease of people living by agriculture was so strong, and the increase in the employment of mothers was not yet so great. By 1975 the employment of mothers had become so high that we can now say that mothers leave their children with someone else for daily care.

$\mathrm{T}$ a b l e 5. The proportion of children whose mothers are farmwives, housewives and employed outside the home 1950-1975.

$\begin{array}{ccccc}\begin{array}{c}\text { Mothers living } \\ \text { in agriculture }\end{array} & \begin{array}{c}\text { House- } \\ \text { wives }\end{array} & \begin{array}{c}\text { Employed } \\ \text { mothers } \\ \%\end{array} & \begin{array}{c}\% \\ \%\end{array} & \text { All } \\ 1950 & 40.3 & 40.4 & 18.3 & \% \\ 1960 & (24.7) & (47.2) & (28.1) & 100.0 \\ 1970 & 15.2 & 38.1 & 46.7 & (100.0) \\ 1975 & 5.31 & 37.8^{2} & 56.9 & 100.0 \\ & & & 100.0\end{array}$

1 Mother a family worker (mostly in agriculture)

2 This figure is not in the statistics, but has been calculated here by reducing the values of the other categories from the total.

Child care became a problem when mothers began to work outside the home. This already occurred in the 19th century. It was then mostly a question of single mothers. One way to solve the problem of child care was to use the same means used in agriculture. But not all mothers had a grandmother or other relative in their neighborhood. They did not even have enough money to hire a servant, though servants in those days were low-paid. In 1909, $15 \%$ of all female manufacturing workers used this form of day care for their children.

Already in an early phase of industrialization it was realized that one way to solve the day care problem was to establish special institutions for that purpose. The first known crèche in Finland was established in Helsinki in 1861. This and some other later-established crèches were organized and supported by charity associations. The shortage of money, however, made them short-lived. More firmly established activities began in 1888 . The stability of the institution was based on the fact that this kindergarten was the first one to receive an allowance from a special semimunicipal association. This was the beginning of the state and municipal 
allowance for the day care of children. Starting in 1913 local authorities in Helsinki began to aid kindergartens regularly, and the state granted money for kindergartens for the first time in its 1917 budget. Time has shown that the day care of children is not possible without the support of the state and local authorities. The costs of day care are very high and they remain high because this kind of activity cannot be rationalized in the way that, for example, food production can be.

The relative increase in state support for day care remained on a low level during the 50's and the first half of the sixties. It began to increase more clearly after 1966 . The reason for this slow increase is probably the fact that the employment of mothers did not increase dramatically in 1946-1965. There were also other possibilities which could be used in those days (nurses) and that is why the pressure for more kindergartens was not so strong. The employment of mothers began to increase decisively in the late 60 's, and at the same time the possibilities for other forms of day care diminished. This obliged the state to react to the situation, especially when women themselves began to demand the expansion of day care facilities. The expansion was really great after the new day care law (1973).

Although the state has increased its economic support of day care and although the number of places in day care centers has increased (Figure 4), especially in the 70 's, the proportion of mothers who can use this form of day care has not changed very much. This is because the number of employed mothers has increased at the same rate. The proportion of all forms of day care can be seen in Table 6 .

$\mathrm{T} \mathrm{a} \mathrm{b} \mathrm{l} \mathrm{e} \mathrm{6.} \mathrm{The} \mathrm{proportion} \mathrm{of} \mathrm{various} \mathrm{day} \mathrm{care} \mathrm{forms} \mathrm{used} \mathrm{by} \mathrm{employed} \mathrm{mothers}$ in 1975 .

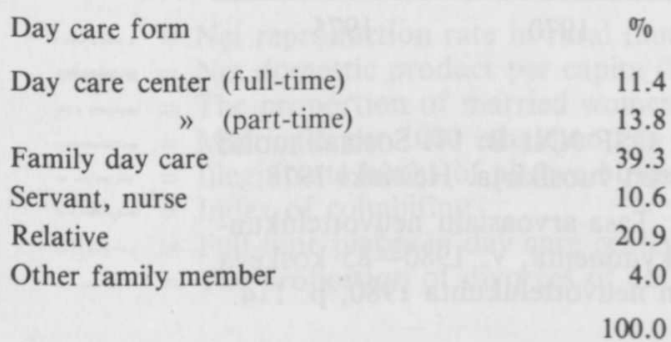

Source: Central Statistical Office: Tilastotiedote, Statistical Bulletin TY 1976: 13, 15.

\section{Conclusions}

According to the data presented above there have been three main periods of societal development in Finland after World War II. The first one was a quite short period just after the War. It was characterized by the instability of the family. We then had a stable phase of about fifteen years, i.e. the fifties and the first half of 
F i g u r e 4. Full-time places in day care centers per 1000 under-7-year-old children.

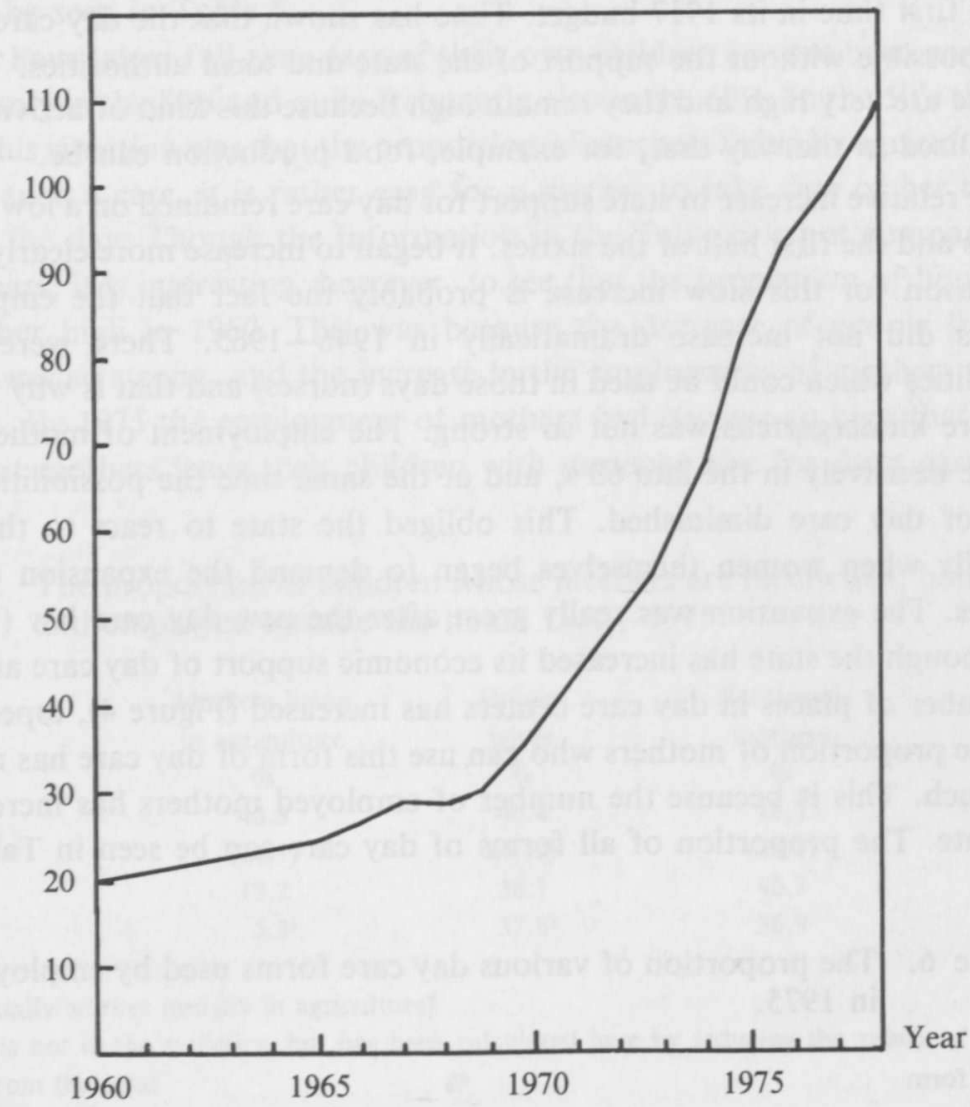

Source: For the years 1960-75: OSF XXI B: 17. Sosiaalihuolto 1975. Sosiaalihuoltotilaston vuosikirja. Helsinki 1978.

For the years 1976-78: Tasa-arvoasiain neuvottelukunnan YK:n naisten vuosikymmentä, v. 1980-85 koskeva ohjelma. Tasa-arvoasiain neuvottelukunta 1980, p. 114.

the sixties. Though societal change had already begun, it was fairly moderate and it contained practically no pressure for a change in family life. During these years family life was quite stable. The third period began in about 1966 and it consisted of a very rapid change in both the societal and family sectors. The core of the change was in 1968-1972, but in some sectors the change continued further into the seventies. Figure 5 illustrates these three periods.

The beginning, or one can also say the source, of the rapid change at the turn 
$\mathrm{F}$ i g u r e 5. Curves expressing the three periods in the state of society in Finland after World War II.

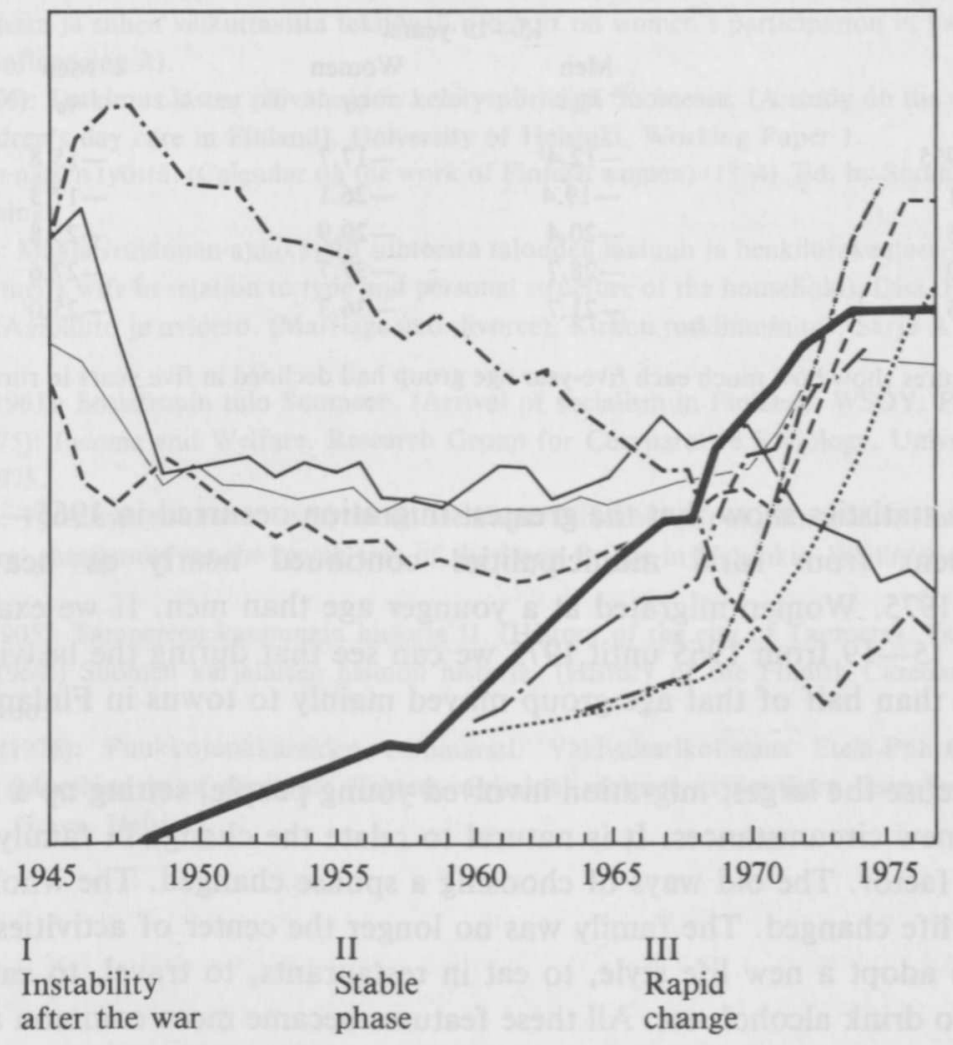

.... = Net reproduction rate in rural municipalities

$=$ Net domestic product per capita $(1948=100)$

-.- $=$ The proportion of married women with income of all married women

$-=$ Marriages per 1000 inhabitants in urban municipalities

--- = Illegitimate births of all live births in urban municipalities

..... = Index of cohabiting

......... = Full-time places in day care centers per 1000 under-7-year-old children

$=$ The proportion of divorces of all dissolved marriages in urban municipalities

of the seventies was the economic growth which began at the turn of the sixties. This was the basis for the change in the industrial structure: the proportions of the manufacturing sector and, even more, the service sector began to increase. The generation which experiences this change most deeply consisted of those young people who were born in 1946 - 50 (the baby boom). The baby boom was mostly a rural phenomenon. These young people migrated to towns in 1965-70, when they were about 20 years old. The extent of the migration can be seen in Table 7 . 
$\mathrm{T}$ a b l e 7. The decrease in each age group in rural municipalities, 1950-1975.

\begin{tabular}{lcccc} 
Period & \multicolumn{2}{c}{$15-19$ years } & \multicolumn{2}{c}{$20-24$ years } \\
& $\%$ & Women & Men & Women \\
& $\%$ & $\%$ & $\%$ & $\%$ \\
$1950-1955$ & $-12.4^{1}$ & -17.7 & -15.8 & -4.2 \\
$1956-61$ & -19.4 & -26.1 & -17.3 & -19.3 \\
$1960-65$ & -20.4 & -29.9 & -23.8 & -19.2 \\
$1965-70$ & -28.7 & -37.7 & -27.6 & -20.9 \\
$1970-75$ & -21.7 & -36.3 & -25.0 & -20.7
\end{tabular}

${ }^{1}$ The figures show how much each five-year age group had declined in five years in rural municipalities.

The statistics show that the greatest migration occurred in 1965-1970, but the movement from rural municipalities continued nearly as heavily through 1970-1975. Women migrated at a younger age than men. If we examine the age cohort 15-19 from 1965 until 1975 we can see that during the heaviest migration no less than half of that age group moved mainly to towns in Finland but also to Sweden.

Because the largest migration involved young people, setting up a family occurred in new circumstances. It is natural to relate the change in family life patterns to this factor. The old ways of choosing a spouse changed. The whole conduct of family life changed. The family was no longer the center of activities. It was then easy to adopt a new life style, to eat in restaurants, to travel, to eat ready-made food, to drink alcohol, etc. All these features became more common at the turn of the seventies. All these also form a whole, which we can call a new societal state or atmosphere, which is expressed by a new life pattern.

We can find two main tendencies in the new life pattern. To a great extent they are opposites. On the one hand we can notice a tendency of socialization of many activities through the state apparatus and private capital. This tendency can also be called enlargement of the public spheres. On the other hand we can find the tendency of privatization, i.e. many phenomena connected with marriage have become more and more private, and are no longer so much controlled by the authorities. Part of the privatization expresses the rise of individualization or subjectivity, which are normally considered good (as the right of the individual). But their social consequences have not all been without disadvantages.

\section{References}

Aromaa, K., Cantell, I. \& Jaakkola, R. (1979): Avoliiton aloittama parisuhde kestää avioliittoalkuisen tapaan. (The pair relationship started without marriage continues like that in marriage). Sosiaalinen aikakauskirja 1979/5. 
Avioliittolakikomitean mietintö I (Report of the marriage law committee). Komiteanmietintö 1972:21, Valtion Painatuskeskus. Helsinki 1972.

Central Statistical Office (1976): Tilastotiedote (Statistical Bulletin) TY 1976/13. Selvitys naisten työhön osallistuvuudesta ja siihen vaikuttavista tekijöistä. (Report on women's participation in paid work and factors influencing it).

Jallinoja, R. (1976): Tutkimus lasten päivähoidon kehityspiirteistä Suomessa. (A study on the development of children's day care in Finland). University of Helsinki. Working Paper 1.

Kalenteri Suomen naisen työstä. (Calendar on the work of Finnish women) (1894). Ed. by Suomen Naisyhdistys, Helsinki.

Saurio, E. (1947): Maalaisemännän ajankäyttö suhteessa talouden laatuun ja henkilörakenteeseen. (Use of time of farmer's wife in relation to type and personal structure of the household). Diss. Helsinki.

Sihvo, J. (1976): Avioliitto ja avioero. (Marriage and divorce). Kirkon tutkimuslaitos, Sarja A N:o 30, Tampere.

Soikkanen, H. (1961): Sosialismin tulo Suomeen. (Arrival of socialism in Finland). WSOY. Porvoo.

Uusitalo, H. (1975): Income and Welfare. Research Group for Comparative Sociology. University of Helsinki 8. 1975.

Waris, H. (1973): Työläisyhteiskunnan syntyminen Helsingin Pitkänsillan pohjoispuolelle. (Emergence of the workers' community on the North side of the Long Bridge in Helsinki). Weilin \& Göös. Helsinki.

Voionmaa, V. (1905): Tampereen kaupungin historia II. (History of the city of Tampere). Tampere.

Voionmaa, V. (1969:) Suomen karjalaisen heimon historia. (History of the Finnish Carelian tribe). WSOY. Porvoo.

Ylikangas, H. (1976): Puukkojunkkareiden esiinmarssi. Väkivaltarikollisuus Etelä-Pohjanmaalla 1790-1825. (Marching in of the knife fighters. Criminal violence in Southern Ostrobothnia in 1790-1825). Otava. Helsinki. 